\title{
Male Perceptions on Female Sterilization: A Community-Based Study in Rural Central India
}

\begin{abstract}
CONTEXT: Use of modern contraceptive methods has increased fourfold in India since the 1970s, characterized by a predominance of female sterilization. There has been considerable investigation about women's choice of female sterilization, but little from the male perspective.
\end{abstract}

METHODS: Seven focus group discussions were conducted among 58 men currently married to women aged 15-45, followed by a cross-sectional survey among 793 men currently married to same-aged women. Bivariate analysis was used for the survey data, and content analysis was used for the qualitative data.

RESULTS: Men's primary source of reproductive health information was mass media, although they expressed interest in getting information through discussion with knowledgeable sources. Men understood family planning and contraception to be two separate issues: Men viewed "family planning" as synonymous with female sterilization, whereas they saw "contraception" as referring to spacing methods, knowledge of which was limited. Thirty-four percent of men reported that their wives had been sterilized; $79 \%$ of men who did not rely on any permanent method said they wanted their wives to be sterilized. In focus group discussions, most men reported themselves as their family's sole decision maker about reproductive health; however, only one-third of survey respondents did so.

CONCLUSION: Men are interested in acquiring family planning information, but lack knowledge about available information sources, which hampers their ability to make informed family planning choices. Family planning service providers and program planners need to be aware of males'knowledge and perceptions pertaining to family planning, and make appropriate modifications to communication strategies. International Perspectives on Sexual and Reproductive Health, 2009, 35(3):131-138
By Arundhati Char, Minna Saavala and Teija Kulmala

Arundhati Char is a doctoral candidate and Teija Kulmala is senior researcher, both in the School of Public Health, University of Tampere, Finland. Minna Saavala is researcher, The Family Federation of Finland, Helsinki, Finland.
Since the 1994 International Conference of Population and Development (ICPD), policymakers have expressed great commitment to moving away from demographic targets toward a broader focus on human welfare, individual choice and gender equality. ${ }^{1,2}$ Similarly, reproductive health practitioners have recognized that the failure to target men has weakened the impact of family planning programs, because men can significantly influence their partners' reproductive health decisions and use of health services, 3,4 especially in societies where women do not possess the same decision-making powers as men. However, gendersensitive strategies have been neglected and, to a large extent, family planning programs have remained female oriented. ${ }^{5-7}$ The literature on men's role in reproduction has increased in recent years, ${ }^{8,9}$ but much of it has focused on demography and fertility. Research is still limited with regard to males' knowledge and perceptions of and attitudes about family planning, contraceptive use and preferences. ${ }^{10}$

Family planning programs implemented in India between the late 1970s and 1990s focused on bringing down fertility levels through vertical programs that emphasized demographic targets and advocated sterilization as the principal family planning method. However, in the spirit of the ICPD, and as a result of dissatisfaction with the overemphasis on demographic targets, insensitivity to client needs, low demographic impact, violation of reproductive rights, neglect of quality and stagnation of the program, India has since made major policy changes. ${ }^{11}$ In 1996, the government initiated the target-free Community Needs Assessment Approach, which involved formulating plans in consultation with communities. ${ }^{12}$ The National Population Policy 2000 clearly set out the demographic goals of the country, but these goals are to be achieved within the framework of gender equity and social development. India thus launched a comprehensive family welfare program, in which all population groups are involved and all modern family planning methods are advocated. ${ }^{13}$ However, according to the latest National Family Health Survey (NFHS-3), two out of three married Indian women aged 15-49 who practice contraception still use female sterilization. ${ }^{14}$ In rural areas, the proportion is even higher, with $70 \%$ of contraceptive users relying on female sterilization. Overall, 37\% of all married Indian women of reproductive age are sterilized.

The present study was conducted in the central Indian state of Madhya Pradesh, one of the country's least developed areas. ${ }^{15}$ Family planning programs in Madhya Pradesh have traditionally focused on women, but because of their subordinate status, women are often not able to make their own decisions regarding family planning or 
health care in general. Therefore, understanding the role of men as "gatekeepers" of family welfare is critical to the success of family planning programs. The aim of this study was to examine how men in rural Madhya Pradesh understand and perceive family planning, paying special attention to male knowledge, perceptions, decision making and reliance on female sterilization.

\section{METHODS}

\section{Study Setting}

The study was conducted in Sehore and Raisen, two districts of Madhya Pradesh. The state has a total population of 60.4 million people, of which about $73 \%$ reside in rural areas. According to the NFHS-3, the total fertility rate is 3.12 for the state overall and 3.34 for rural areas, which are higher than the comparable national rates of 2.68 and 2.98 , respectively. ${ }^{14}$ About $70 \%$ of the residents of Madhya Pradesh depend on agriculture for their income. The sex ratio at birth is 933 females per 1,000 males, the birth rate is 32.3 per 1,000 persons, and about $50 \%$ of women and $70 \%$ of men are literate. ${ }^{16}$

\section{Data Collection and Analysis}

The data were drawn from a larger study, "Male Involvement in Reproductive Health in Central India," conducted to identify strategies for positively influencing men's reproductive health-seeking behavior, including participation in fertility regulation, practice of safe sex, support of maternal and child health, and prevention of unwanted pregnancies.

We used a multimethod approach, including focus group discussions and a cross-sectional survey, because we believed that a study of a little-researched phenomenon, in this case male involvement, would benefit from varied methods and contexts. The focus groups and the survey represented public and private contexts, respectively. In addition, the survey enabled generalization of findings emerging from the focus groups. Combining the two methods also helps to bring into focus the varied social aspects of fertility and broadens our understanding of the social mechanisms of demographic phenomena, which are often difficult to capture through surveys. ${ }^{17}$

Data collection occurred in three phases between November 2004 and August 2005: pilot testing of data collection tools, focus group discussions and the survey. Currently married men with spouses of reproductive age (15-45 years) were eligible to participate in the study; those who took part in a focus group were excluded from the survey. Informed consent was obtained from each participant.

* Indian states are divided into districts, which are further divided into blocks (or tehsils), which are further divided into villages. Based on the Census of India (2001), the village-level information is compiled and available from the block development officer for all villages in that block. The female literacy rate for each village in the selected block was obtained from this office.

†The government voters' list contains names and household numbers of eligible men and women older than 18 (which is the eligible age for voting in India). The most recent list available was from 2004.
For the present study, both men whose wives had been sterilized and those whose wives had not were presented with questions regarding their perceptions of female sterilization, decision to adopt the method, use of the method and the chief family planning decision maker in the family. The responses of men whose wives had been sterilized reveal their experience with making actual decisions; the responses of others provide information about the expected norms in sterilization decision-making situations.

- Focus group discussions. To gather a homogeneous group of men who would provide credible information about practices and norms in their community, we used snowball sampling ${ }^{18}$ to recruit participants-men currently married to women aged between 15 and 45-in the seven villages included in the study. Overall, 58 men agreed to participate. Discussions were conducted in the local language (Hindi), and lasted approximately two hours. Two experienced male moderators facilitated the discussions. The principal moderator used a pretested guide to direct the discussion, while the co-moderator noted nonverbal cues observed during the discussions. Focus groups were tape-recorded, transcribed verbatim in Hindi and then translated into English. To validate the tapes, we checked them against the translated text for inaccuracies. Data were analyzed by qualitative content analysis, using Atlas TI software.

- Cross-sectional survey. We used findings from the focus group discussions to develop the survey questionnaire, which aimed to quantify and complement the qualitative information.

In each district, villages were randomly selected by first identifying those with a population of at least 1,000 people; the decision to select larger villages was based mainly on logistical reasons. For selected villages, we obtained the best estimates available of female literacy. * Villages in each of the two districts were divided into low, medium and high literacy levels; four villages were randomly selected from each group, resulting in a total of 24 villages. We used a systematic sampling method with a random start for the selection. Because of resource and time limitations, it was not possible to carry out a detailed household listing within each village, so the most up-to-date voters' list was used as a sampling frame. ${ }^{\dagger}$ About 30 households with eligible men were selected from each village using random sampling with a random start, resulting in a sample of 793 respondents.

Twelve male postgraduate students with social sciences background were recruited from the local state university to be research investigators. Once trained, the research investigators conducted a household survey with the selected men. The survey questionnaire asked men about their socioeconomic and demographic characteristics, sources of family planning information, understanding and usage of family planning, and knowledge and perceptions of reversible contraceptives and female sterilization. The instrument was pretested extensively in areas comparable but not adjacent to the study sites. Because the interviews required privacy, the investigators would take respondents 
outside of their houses, if necessary, to an area in or around the village where they would not be disturbed. Each participant gave oral informed consent after being provided with details of the purpose of the research. A $10 \%$ back-check of questionnaires per village was carried out by research supervisors, who also scrutinized all questionnaires on the same day that they were filled, to check for completeness, consistencies and clarity of marked codes. Data were analyzed using SPSS (13.0).

\section{RESULTS}

\section{Background Characteristics}

The average age of survey respondents was 30.6 years (Table 1 ). Half of men reported having less than a secondary level education. Nearly all (94\%) were Hindu; among Hindus, $60 \%$ belonged to the locally dominant lower caste administratively labeled as "other backward classes." Two-thirds of men depended on agriculture for their source of living. Thirty-eight percent reported a monthly family income of below 1,000 rupees, $39 \%$ between 1,000 and 2,500 rupees, and $23 \%$ above 2,500 rupees. *

Nearly all men (98\%) had heard of contraceptives. Twenty-nine percent reported currently using a temporary family planning method. Thirty-four percent relied on female sterilization; of these, two-thirds reported that female sterilization was the first method of family planning they had ever adopted, and one-third had used a spacing method before sterilization (not shown).

On average, men were 20 years old at marriage. About half $(52 \%)$ reported having a family that consisted of more than just the couple and their children. Men's mean number of children ever born and living were 2.8 and 2.5 respectively (not shown); on average, they had 1.8 living sons and 1.7 living daughters. The average number of living children among men whose wife was sterilized was 3.4; the number among men whose wife was not sterilized was 2.1.

Overall, such background characteristics as education, age, number of children and caste of the focus group participants (not shown) were no different from those of the survey respondents. The age of the discussants ranged from 22 to 39 years (average, 30.8). About half of focus group participants had less than a secondary education; only $7 \%$ were illiterate. The majority were Hindus who belonged to other backward castes.

\section{Male Concepts of Family Planning}

According to the focus group discussions, men were familiar with the local terms for contraception, but their understanding of the terms was different from the definitions used in government family planning communication campaigns. For example, the government uses the term "garbha nirodhan" to mean any form of contraception, including sterilization; however, men understood this term to be a means of spacing or delaying pregnancies, not including

*In August 2005, US\$1=Rs. 44.
TABLE 1. Background characteristics of men currently married to women aged 15-45, Madhya Pradesh, India, 2005

$\begin{array}{ll}\text { Characteristic } & \text { Mean or } \\ & (\mathrm{N}=793)\end{array}$

Mean age $30.6(5.4)$

\section{Age}

20-24 14.8

25-29 27.1

30-34 27.1

$\geq 35 \quad 31.0$

Education

None

Primary

Middle

$\begin{array}{ll}\geq \text { secondary } & 48.6\end{array}$

Religion

Hindu

Muslim

Other

5.7

0.2

Caste*

Upper

Scheduled caste

Scheduled tribe

Other backward

18.9

16.7

4.7

59.7

Occupation

Agricultural

Nonagricultural†

Unemployed

67.1

32.0

Monthly family Income

Low (<Rs. 1,000)

5.7

27.5

8.6

Medium (Rs.1,000-2,500)

High (>Rs. 2,500)

Mean age at marriage

Age at marriage

$\leq 15$

16-18

$19-20$

11.5

20.3

27.6

$\geq 21$

40.6

Family type

Nuclear $\quad 48.2$

$\begin{array}{ll}\text { Joint‡ } & 51.8\end{array}$

Has heard of contraceptives

Yes

Current contraceptive use

Temporary methods $\quad 29.3$

Female sterilization $\quad 33.9$

None $\quad 36.8$

Mean no. of children

Wife sterilized

$3.4(1.2)$

Wife unsterilized

$2.1(1.7)$

*Among Hindus ( $\mathrm{N}=746$ ). Includes casual laborers, teachers, drivers, small businessmen and community workers. Includes families made up of more than just a couple and their children. Note: Figures in parentheses are standard deviations.

sterlization. Similarly, the term "garbha nirodhak sadhane" is used by campaigns to refer to all forms of family planning methods, including permanent procedures; however, men understood it to refer only to temporary modern contraceptive methods, such as the pill and condoms. Finally, most men commonly understood the general term 
for family planning, "parivar niyojan," to be synonymous with sterilization-a method adopted once one's desired family size is reached, involving an operation that permanently stops further births. As one discussant said:

"Parivar niyojan is done after we have our desired number of children."-32-year-old, fifth-grade education

Another focus group participant commented:

"About parivar niyojan, I only know this much, that by getting the operation (sterilization) done, conception stops and children are not born afterwards."-33-year-old, 12th-grade education

Furthermore, the general term for sterilization "nasbandi," which literally means "tying the tubes," was mainly used by men in the focus groups to mean the more popular "mahila nasbandi" or female sterilization.

\section{Family Planning Knowledge}

Among men who participated in the survey, $81 \%$ mentioned, unprompted, at least three methods by which conception can be either delayed or avoided (Table 2). Ninety-seven percent mentioned condoms, $85 \%$ the pill and $83 \%$ female sterilization. Among those who spontaneously mentioned female sterilization, 35\% mentioned it as the first option (not shown). Another 15\% confirmed awareness of female sterilization when asked specifically whether they had heard of it.

Although men could name various family planning methods, the qualitative data revealed that their knowledge of the methods was superficial. Men commonly mentioned their limited information about contraceptive methods and asked the moderator to provide a more accurate explanation. One discussant said:

"We do not know what family planning is, so what will we tell you? You tell us, then."-30-year-old, no education

Another participant commented:

"Parivar niyojan is this only, that there should be a small family, there should not be children in great numbers, what else? It means nasbandi."-33-year-old, seventh-grade education

When they were asked by the moderator if they had heard about any methods other than nasbandi (steriliza-

\begin{tabular}{|c|c|}
\hline Measure & $\%$ \\
\hline No. of methods mentioned & $(\mathrm{N}=793)$ \\
\hline 0 & 1.6 \\
\hline 1 & 2.0 \\
\hline 2 & 15.3 \\
\hline$\geq 3$ & 81.1 \\
\hline Methods mentioned & $(\mathrm{N}=780)$ \\
\hline Condom & 97.4 \\
\hline Pill & 85.0 \\
\hline Female sterilization & 83.4 \\
\hline IUD & 33.6 \\
\hline Injectable & 11.2 \\
\hline Male sterilization & 1.8 \\
\hline Abstinence & 1.8 \\
\hline Other & 1.8 \\
\hline
\end{tabular}

tion), one man responded:

"We know of other means, but no one has adopted them.-26-year-old, seventh-grade education

Another commented:

"We only use nasbandi.-38-year-old, fourth-grade education

And another said:

“There are many things. We don't even know what they do properly. Now you tell, only then will we come to know."-28-year-old, 10th-grade education

\section{Primary Source of Family Planning Information}

According to the survey, men most commonly learned about family planning from the mass media, with $58 \%$ reporting television or radio as their primary source of information. Only 24\% reported receiving information primarily from village health workers, $9 \%$ nongovernmental organization workers, $7 \%$ friends and $2 \%$ family or other sources.

During the focus groups, men indicated that women had better and more direct access to information through the village health workers. As a result, men sometimes saw their wives as important sources of information on family planning. One man said:

"The ANM (auxiliary nurse midwife) gives [information] to the women only. Our wives sometimes discuss with us about what they learn from [her]."-30-year-old, 10th-grade education

Peer groups were another important source of information. One discussant said:

"We get some information from our friends in the village. The one who knows, tells....Other people hear of it and then come and tell us, and we then tell some others, and so on."-28-year-old, 10th-grade education

Furthermore, as in the survey, men in the focus groups cited television as an important information source, but also addressed their urgent need for more direct and personal contact with someone knowledgeable:

R1: Sometimes [they] give information on television also.-27-year-old, eighth-grade education

R2: Yes, TV is important but we have so many questions on parivar niyojan. Whom do we ask?-35-year-old, seventhgrade education

M: Besides TV and friends, do you get information from anywhere else?

R1: We get to know a lot from this type of discussion, like the one we are now having.

R2: Like you people have come, if [people] keep coming like this, give us information, we will get information and become aware....And if we have any problems or questions, we could ask them.

Discussions from another focus group also brought out the need for more interpersonal communication on family planning-28-38-year-olds, average 8.0 years education:

R1: As such, sir, there should be a health center in the village.

R2: Or at least, sir, someone who knows should come 
and talk to us about these issues.

R3: Now when there is no one, if there is a problem, who do we ask?

R4: [We] should keep getting information from people who are knowledgeable.

\section{Reasons for Female Sterilization Preference Among Men}

The vast majority (93\%) of men who were not relying on a permanent method at the time of the survey indicated their willingness to adopt sterilization in the future, including $79 \%$ who said their wives would adopt female sterilization (Table 3). Only $2 \%$ of men were unwilling to adopt either type of sterilization, and $4 \%$ were not sure (not shown). The main reasons cited by men who said their wives would adopt female sterilization were that "only women undergo sterilization and not men" (31\%) and that "it is the wish of the husband [that the wife gets it done]" (19\%).

In the focus group discussions, men also cited social and cultural reasons for adopting female sterilization. For example, one man stated:

"Men work hard for the family, while women stay at home."-25-year-old, no education

And another man said:

"If I get it done, people will laugh at me and say, "Why are you doing the women's thing?"'-32-year-old, eighthgrade education

And regarding the economic implications, a discussant stated:

"If we do not get [female sterilization] done, there will be more children, the family size will increase and then there will be many more problems."-37-year-old, eighthgrade education

\section{Male Sterilization}

Most men did not consider male sterilization, or "purush nasbandi," to be a feasible option. In the focus group discussions, when the moderator would try to begin a dialogue on male sterilization, men would often steer the discussion toward female sterilization. One respondent stated:

"Male sterilization is...very unpopular. Due to inadequate information, people talk of various side effects of the method like men become weak, men cannot do any heavy work, limbs become weak and painful, and men get cold and fever."-33-year-old, seventh-grade education

Another man said:

"We are willing to get operated. But someone will have to give us complete information about the method, convince us that there will be no problems with it; that a man does not start lacking in anything [become impotent] after the operation."-28-year-old, 10th-grade education

Men went on to state that male sterilization is almost never discussed, either with women or men. "Why talk about male sterilization when women are ready to get sterilized?" was a common response among discussants. This partly reflects the fact that male sterilization is not often brought up as an option by the local health workers.
TABLE 3. Percentage of currently married men whose wives were not sterilized, by willingness to adopt sterilization and reasons for choosing female sterilization

Measure $\%$

Willingness to adopt sterilization ( $\mathrm{N}=496)$ 93.1

Female sterilization

Male sterilization

Reasons for choosing female sterilization $(\mathrm{N}=390)$

In villages, only women undergo sterilization

Husband's wish

No more children

Man works hard to earn money; woman stays home

Based on couple discussion

Only trusted method

Wife's wish

Other*

Cannot say

14.5

*Includes advantage for women, male sterilization problematic, heard of only female sterilization, religious reasons, economic reasons and parents' wish.

\section{Perceptions of Dissatisfaction: Female Sterilization}

Despite female sterilization being the most common currently or potentially used method among men's wives, men voiced dissatisfaction with the method, including certain undesirable side effects or method failure. For example, one discussant commented:

"We know that female sterilization has failed in many cases. Women have conceived even two years after getting [an operation]." -29-year-old, seventh-grade education

In the survey, both men whose wives had been sterilized and those whose wives had not done so spontaneously reported perceiving specific negative side effects associated with sterilization, like general weakness and excess weight gain (Table 4). Thirty-seven percent of men with a nonsterilized wife believed their wife would not experience any changes if she were sterilized or said they were not sure if any such changes would occur; none of the men whose wife had been sterilized reported no changes after sterilization or not being sure.

In some focus groups, men stated that weakness was a side effect of the method:-28-36-year-olds, average seventhgrade education:

\begin{tabular}{|c|c|c|}
\hline Side effect & $\begin{array}{l}\text { Wife sterilized } \\
(\mathrm{N}=269)\end{array}$ & $\begin{array}{l}\text { Wife not sterilized } \\
(\mathrm{N}=496)\end{array}$ \\
\hline Weakness & 69.4 & 44.2 \\
\hline Weight gain & 26.1 & 7.5 \\
\hline Increased strength/health & 2.5 & 4.8 \\
\hline $\begin{array}{l}\text { Pain of surgery remains/ } \\
\text { operation can be risky }\end{array}$ & 1.0 & 4.6 \\
\hline Other* & 1.2 & 1.2 \\
\hline $\begin{array}{l}\text { Does not get pregnant } \\
\text { ever again }\end{array}$ & 0.6 & 0.2 \\
\hline None & 0.0 & 10.7 \\
\hline Cannot say/unsure & 0.0 & 26.8 \\
\hline Total & 100.0 & 100.0 \\
\hline
\end{tabular}


M: Do you know about female sterilization?

R1: Yes, [we] know. Here, a Silawat [caste] has had it done. Earlier, his wife looked very nice and healthy, but after the operation [sterilization], the poor wife has absolutely become very thin, almost all skin and bones. The poor husband is very troubled.

R2: Yes, sir. Weakness sets in with female sterilization.

R3: There are complaints of back and stomach pain, too.

\section{Men's Roles as Family Planning Decision Makers}

Although men felt that they did not have enough or accurate information on temporary methods or tubal sterilization, about one-third (31\%) of survey respondents reported that they themselves were the main decision makers with regard to reproductive health (not shown). Fifty-eight percent of men said that they made such decisions jointly with their wife. Small proportions (2-3\% each) of men said that their wife alone or one or both of their parents made reproductive health decisions.

The results of the focus groups were somewhat different than those of the survey. During discussions, men represented themselves as the main decision makers, both with regard to general household decisions and family planning acceptance. For example, a 28-year-old with 10 years of education who had been married for six years stated "In my family, only one brain works, and that is mine. So, if there are any decisions, it is I who make [them]."

\section{DISCUSSION}

In rural Madhya Pradesh, female sterilization has remained the predominant method of contraception, despite long-term efforts by the government to promote other methods. Our experience in implementing a comprehensive reproductive health program in the area in 2001-2005 revealed a need for greater clarity on how couples viewed family planning and the role men played. Although men's knowledge, attitudes and perceptions in regard to family planning have received some attention in India, ${ }^{19}$ the current literature does not address men's conceptualization of family planning. According to our results, men conceptualize family planning in ways different from the government family planning promotion campaigns. An understanding of local terminologies and concepts used by men would help policymakers and program planners devise and implement more effective strategies to promote reversible contraceptive methods.

Males' knowledge of temporary contraceptive methods was mostly limited to their names. Similar to findings from the 2005-2006 National Family Health Survey, the results of our survey show that mass media were men's primary source of family planning information. In addition, our findings are in line with a national report indicating that half of men are exposed to such messages through television and radio, and fewer than one-fourth receive information through interpersonal communication with health workers. ${ }^{14}$

Thus, our results confirm that in Madhya Pradesh, fami- ly planning messages have seldom been aimed at men and suggest that it would be beneficial to use multiple channels for information dissemination. Television and radio may be major sources of information, as they are very popular among the rural population; however, mass media messages tend to be rather generic, and viewers are unable to ask questions and have their doubts clarified. Even though few men received information from health workers, they said they wanted more interpersonal discussions with knowledgeable persons. Some men mentioned getting information from their wives, who are the primary recipients of family planning information in the villages. This underlines the importance of couple communication in family planning, as well as the need to ensure that both men and women in the community have full and accurate information.

Although the Indian Family Planning Program has adopted new policies over the last 15 years (for example, the target-free approach in 1996 and the National Population Policy in 2000), it continues to be skewed toward female sterilization. Female sterilization is still the most frequently used contraceptive method in Madhya Pradeshused by $47 \%$ of all currently married women aged 15-49. ${ }^{14}$ Overall, in our study, female sterilization was the most common method among those practicing contraception and the method mentioned most often by those intending to use a method. Also, for most couples who had adopted it, female sterilization was the first method ever used. This confirms that couples rarely either delay their first birth or space subsequent births.

Men's reasons for opting for female sterilization were based mainly on social norms that assign the burden of family planning to women. Men claimed to be influenced by social, cultural and economic factors, as well as by peer pressure, to get their wives sterilized. One of these factors, according to men, is that women do not do labor-intensive work and mostly stay at home. In addition, men were apprehensive about male sterilization, believing that it would lead to weakness and worrying that something might go wrong during the procedure. These findings are similar to observations in Uttar Pradesh. ${ }^{20}$ Men feel that the sterilization operation is easier to perform on women than on men, ${ }^{20}$ although vasectomy is in fact a safer and less invasive procedure than tubal sterilization. ${ }^{21}$ Furthermore, men say that the predominance of female sterilization results from lack of sufficient information about other contraceptive choices, and is not always based on the method's desirability per se.

Both men whose wives had been sterilized and those whose wives had not done so talked about understanding the physical hardships women face on account of sterilization. Men expressed concern for their wives and often perceived that their wives experienced side effects from sterilization; such responses are similar to those previously reported in rural India. ${ }^{22}$

Although these ideas may, at least in part, be based on myths, rumors and misconceptions about the method, the men in our study displayed their concern about, or at least 
their consciousness of, potential negative effects of sterilization on the physical well-being of their wives, as opposed to the normal perception of rural Indian men as callous and unconcerned about women's health. However, to make an informed choice, men need to be better educated, so that they can dispel myths and rumors about side effects associated with female sterilization.

According to our survey results, only one-third of men reported being their family's sole decision maker in regard to family planning issues. In front of other men in the focus group discussions, however, men more often presented themselves as the main decision makers. In many rural settings, males often dominate decision making on important family matters, including those concerned with reproduction, family size and contraceptive use. ${ }^{20,23,24} \mathrm{Re}$ cent reports suggest men have a strong interest in family planning and other reproductive health issues, ${ }^{24-26}$ and if educated about women's and men's reproductive systems, contraceptive methods and access to specific services, men may be encouraged to involve their wives in discussions and together make reproductive health decisions. ${ }^{7}$ Our study corroborates these findings.

\section{CONCLUSIONS}

Although men are aware of various family planning methods, they do not have adequate information about all available methods. This results in most men encouraging their wives to adopt female sterilization, as it is the method most often discussed in the community. It is therefore important to equip men with complete contraceptive information and correct their misperceptions about methods so that they and their wives can choose the method that is best for them.

To achieve this goal, policymakers and program planners need to understand local concepts, experiment with multiple information channels and design strategies for reaching men. In addition, programs must continue to encourage couple communication, so that couples' family planning decisions are made jointly. Some potential strategies suggested by our findings for involving men in family planning programs involve face-to-face dissemination of information by knowledgeable persons, encouraging couple communication within communities, training male health workers to discuss family planning with male groups, and strengthening access to and availability of reversible methods, so that dependence on female sterilization is reduced.

\section{REFERENCES}

1. Green CP et al., Male involvement in reproductive health including family planning and sexual health, United Nations Population Fund (UNFPA) Technical Report, 1995, No. 28, p.104.

2. World Health Organization (WHO), Report of the Meeting of WHO Regional Advisers in Reproductive Health WHO/PAHO, Washington, DC, Sept. 5-7, 2001, Geneva: WHO, 2002.

3. Drennan M, Reproductive health: new perspectives on men's participation, Population Reports, 1998, Series J, No. 46.

4. Mbizvo MT and Basset MT, Reproductive health and AIDS prevention in Sub-Saharan Africa: the case for increased male participation, Health Policy and Planning, 1996, 11(1):84-92.
5. Programme of action of the 1994 International Conference on Population and Development, chapters I-VIII, Population and Development Review, 1995, 21(1):187-213.

6. Ringheim K, When the client is male: client-provider interaction from a gender perspective, International Family Planning Perspectives, 2002, 28(3):170-175.

7. Raju S and Leonard A, eds., Men as Supportive Partners in Reproductive Health: Moving from Rhetoric to Reality, New Delhi: Population Council, 2000.

8. Jejeebhoy SJ, Convergence and divergence in spouses' perspectives on women's autonomy in rural India, Studies in Family Planning, 2002, 33(4):299-308.

9. Varkey LC et al., Involving Men in Maternity Care in India, New Delhi: Population Council, 2004.

10. Stycos JM, Men, Couples, and Family Planning: A Retrospective Look, Cornell University Population and Development Program Working Paper, Ithaca, NY, USA: Cornell University, 1996, Series 96, No. 12.

11. Sangwan $N$ and Maru RN, The target-free approach: an overview, Journal of Health Management, 1999, 1(1):71-96.

12. Ministry of Health \& Family Welfare of India, Community Needs Assessment Approach in Family Welfare Programme, <http://mohfw. nic.in/cnaa.htm>, accessed Aug. 21, 2008.

13. International Institute for Population Sciences (IIPS), National Population Policy 2000, International Institute for Population Sciences Newsletter, 2001, 42(1-2):4-8.

14. IIPS, Key findings from National Family Health Survey-3, 2005-2006, <http://www.nfhsindia. org/factsheet.html>, accessed Dec. 4, 2006.

15. Directorate of Institutional Finance, Government of Madhya Pradesh, India, Madhya Pradesh Human Development Report 2007, <http://www.dif.mp.gov.in/mphdr2007.htm>, accessed Sept. 22, 2008.

16. Registrar General, India, Census of India, New Delhi: Government of India, 2001.

17. Greenhalgh S, Towards a political economy of fertility: anthropological contributions, 1990, Population and Development Review, 16(1):85-106

18. Lopes CS et al., The lack of selection bias in a snowball sampled case-control study on drug abuse, International Journal of Epidemiology, 1996, 25(6):1267-1270.

19. Singh A, Male Involvement in Family Planning and Maternal Care: Evidence from Rural Ahmednagar, Maharashtra, Mumbai: IIPS, 2007.

20. Khan ME and Patel BC, Male Involvement in Family Planning: A Knowledge, Attitude, Behaviour and Practice Survey of Agra District, New Delhi: Population Council, 1997.

21. UNFPA, State of the World Population Report 2000, New York: UNFPA, 2000, p. 31

22. Säävälä M, Understanding the prevalence of female sterilization in rural South India, Studies in Family Planning, 1999, 30(4):288-301.

23. Murthy $\mathrm{N}$ et al., Dismantling India's contraceptive target system, in: Habarland $\mathrm{N}$ and Measham D, eds., Responding to Cairo: Case Studies of Changing Practice in Reproductive Health and Family Planning, New York: Population Council, 2002.

24. Balaiah D et al., Contraceptive knowledge, attitudes and practices of men in rural Maharashtra, Advances in Contraception, 1999, 15(3): 217-234.

25. Collumbien M and Hawkes S, Missing men's message: does reproductive health approach respond to men's health needs? Culture, Health and Sexuality, 2000, 5(7):37-44.

26. Wegner MN et al., Men as partners in reproductive health: from issues to action, International Family Planning Perspectives, 1998 24(1):38-42.

\section{RESUMEN}

Contexto: El uso de métodos anticonceptivos modernos se ha cuadruplicado en India desde los años setenta y se ha caracte- 
rizado por el predominio de la esterilización femenina. Ha habido considerables esfuerzos de investigación sobre la elección de la esterilización femenina que hacen las mujeres, pero existen pocos estudios desde la perspectiva masculina.

Métodos: Siete sesiones de grupos focales se condujeron con 58 hombres actualmente casados con mujeres en edades de 15-45 años, seguidas por una encuesta transversal aplicada a 793 hombres actualmente casados con mujeres del mismo grupo de edad. Se usó análisis bivariado para los datos de la encuesta y análisis de contenido para los datos cualitativos.

Resultados: Para los hombres, la fuente primaria de información sobre salud reproductiva fue los medios masivos, aunque ellos expresaron interés en obtener información a través de charlas con gente informada en el tema. Los hombres encuestados entendieron la planificación familiar y la anticoncepción como dos temas separados: los hombres percibieron la "planificación familiar" como sinónimo de esterilización femenina, mientras que se refirieron a la "anticoncepción" como métodos de espaciamiento, cuyo conocimiento fue limitado. Treinta y cuatro por ciento de los hombres reportaron que sus esposas habian sido esterilizadas; 79\% de los hombres que no dependían de algún método permanente dijeron que querían que sus esposas fueran esterilizadas. En las sesiones de grupo, la mayoría de los hombres se identificó como el único tomador de decisiones en su familia respecto a la salud reproductiva; sin embargo, solamente un tercio de los hombres encuestados se identificó de esa forma.

Conclusión: Los hombres están interesados en obtener información sobre planificación familiar, pero desconocen las fuentes disponibles que pueden consultar, lo cual limita su capacidad para tomar decisiones informadas sobre planificación familiar. Los prestadores de servicios y planificadores de programas de planificación familiar deben estar conscientes del conocimiento y percepciones de los hombres en relación con la planificación familiar, y realizar las modificaciones apropiadas a sus estrategias de comunicación.

\section{RÉSUMÉ}

Contexte: La pratique de la contraception moderne a quadruplé en Inde depuis les années 1970. Elle se caractérise par une prédominance de la stérilisation féminine. De nombreuses études ont été menées sur le choix féminin de la stérilisation. La perspective masculine n'est en revanche guère connue.

Méthodes: Sept réunions de groupe ont été organisées avec 58 hommes mariés à des femmes de 15 à 45 ans. Une enquête transversale a ensuite été menée auprès de 793 hommes mariés à des femmes de la même tranche d'âge. L'analyse bivariée a été utilisée pour les données d'enquête, et l'analyse de contenu pour les données qualitatives.

Résultats: Pour les hommes, les médias représentent la principale source d'information sur la santé génésique. Ils expriment cependant un certain intérêt à s'informer par discussion auprès de sources compétentes. Les hommes voient dans la planification familiale et la contraception deux questions distinctes: la «planification familiale» est pour eux synonyme de stérilisation féminine, tandis que la «contraception» désigne les méthodes d'espacement, au sujet desquelles ils ne sont guère informés. Trente-quatre pour cent des hommes ont déclaré que leur femme était stérilisée; 79\% de ceux qui n'avaient pas eu recours à une méthode permanente ont indiqué désirer que leur femme se fasse stériliser. Lors des discussions de groupe, la plupart des hommes se sont déclarés les seuls décideurs de leur famille en matière de santé génésique, par rapport à un tiers seulement des répondants à l'enquête.

Conclusion: Les hommes désirent s'informer sur la planification familiale mais ils ignorent les sources d'information disponibles, ce qui entrave leur aptitude à opérer des choix éclairés en la matière. Les prestataires de services et les planificateurs de programmes de planification familiale doivent être sensibles aux connaissances et aux perceptions masculines et ajuster en conséquence leurs stratégies de communication.

\section{Acknowledgments}

The authors thank the Academy of Finland for supporting the field work for this study (grant SA205648). The authors also thank the Doctoral Programs in Public Health of the University of Tampere, Finland, The Family Federation of Finland, Helsinki, Finland, and DKT India, Mumbai, India, for their support in analysis and the writing of this article.

Author contact:arundhati.char@uta.fi 